\title{
Dengue Co-infection and COVID-19 in Brazil, 2020: Literature Review
}

\author{
Paulo Marco da Silva Barbosa ${ }^{1}$; Andrezza Fabianni Pedrosa dos Santos Lima² ${ }^{2}$ Emilly Tainá Batista \\ da Silva ${ }^{3}$; Emivaldo Batista da Silva ${ }^{4 *}$; Joana Bulhões Alvares da Silva Lima ${ }^{5}$; Julievelly Vanderley \\ Tenório Ferreira ${ }^{6}$; Rebeca Martins Pereira Damasceno ${ }^{7}$; Bruna Magbis Luna Nascimento Baroni ${ }^{8}$; \\ Maria Mayara Santos Timóteo do Nascimento ${ }^{9}$; Floriano Martiniano Alves Neto ${ }^{10}$; Marcia Maria \\ Queiroz da Silva ${ }^{11}$; Emanuella Barros de Souza Oliveira Alvares ${ }^{12}$
}

1,4.5,11 Department of Pharmaceutical Sciences, University Center of Vitória de Santo Antão - UNIVISA, Vitória de Santo Antão

2.10 Department of Nutrition, Centro Universitário da Vitória de Santo Antão - UNIVISA, Vitoria de Santo Antão

3 Department of Biomedicine, University Center of Vitória de Santo Antão - (UNIVISA) Vitoria de Santo Antão

6.7, 8, 9 Department of Physiotherapy, Federal University of Pernambuco - UFPE, Recife

12 Department of Biology, Center for Biological Sciences, Professor of the Degree Course in Biology, University Center of Vitória de Santo Antão (UNIVISA), Vitória de Santo Antão, Brazil

E-mail adresses: Paulo.22017186042@univisa.edu.br1 (Paulo Marco da Silva Barbosa), andrezzafpslima@hotmail.com2 (Andrezza Fabianni Pedrosa dos Santos Lima), emilly.taina@hotmail.com3 (Emilly Tainá Batista da Silva), emivaldobatista4@gmail.com4 (Emivaldo Batista da Silva), joanafarmacia2018@gmail.com5 (Joana Bulhões Alvares da Silva Lima), julievellyvanderley@gmail.com6 (Julievelly Vanderley Tenório Ferreira), recebamartinspd@gmail.com7 (Rebeca Martins Pereira Damasceno), magbisbruna@gmail.com8 (Bruna Magbis Luna Nascimento Baroni), mariamayarast@gmail.com9 (Maria Mayara Santos Timóteo do Nascimento), Floriano_alves1993@hotmail.com10 (Floriano Martiniano Alves Neto), marcia.201924065@univisa.edu.br11 (Marcia Maria Queiroz da Silva),emanuella.barros@hotmail.com12 (Emanuella Barros de Souza Oliveira Alvares).

${ }^{*}$ Corresponding author

\section{To cite this article:}

Barbosa, P.M.S.; Lima, A.F.P.S.; Silva, E.T.B.; Silva, E.B.; Lima, J.B.A.S.; Ferreira, J.V.T.; Damasceno, R.M.P.; Baroni, B.M.L.N.; Nascimento, M.M.S.T.; Neto, F.M.A.; Silva, M.M.Q.; Álvares, E.B.S.O. Dengue Co-infection and COVID-19 in Brazil, 2020: Literature Review. International Journal of Sciences. Vol. 3, No. 1, 2022, pp.10-14. ISSN 2763-5392.

Received: 11 24, 2021; Accepted: 12 26, 2021; Published: 01 15, 2022

\begin{abstract}
The pandemic scenario, accompanied since the end of 2019, consisting of COVID-19 affects countries on all continents. Upon reaching South America, it expressed concerns to researchers about the simultaneous circulation of existing dengue serotypes. This is a national and international literature survey involving dengue co-infection and covid-19 in Brazil. The reference period was from April 2020 to March 2021. The descriptors used were: "Coinfection" AND "simultaneous infection" AND "Sars Cov II" AND "Arbovirus". The survey took place in the PERIODIC CAPES and Google Scholar databases in both databases. It was found that the possibility of co-infection between Dengue and COVID-19 exists, mainly in endemic areas, which may lead to a delay in the diagnosis of COVID-19 infection, producing greater dissemination of the virus and progression to death.
\end{abstract}

Keywords: Arbovirus. Co-infection. Cov Sars II.

\section{Introduction}

The pandemic scenario, accompanied since the end of 2019, consisting of COVID-19, affects countries on all continents. Upon reaching South America, it expressed concerns to researchers about the simultaneous circulation of existing dengue serotypes (MUHAMMAD ALI,2020).

Regarding the classification of COVID-19, it is described in the literature as an emerging disease caused by the new coronavirus, offering impacts on society, especially in health systems, due to the rapid and contagious infectious cycle (MIRZA RYAN, 2020). 
2 Barbosa, P.M.S.; Lima, A.F.P.S.; Silva, E.T.B.; Silva, E.B.; Lima, J.B.A.S.; Ferreira, J.V.T.; Damasceno, R.M.P.; Baroni, B.M.L.N.; Nascimento, M.M.S.T.; Neto, F.M.A.; Silva, M.M.Q.; Álvares, E.B.S.O. Dengue Co-infection and COVID-19 in Brazil, 2020: Literature Review...

In addition to presenting itself as a disease of easy dissemination, the impacts of this virus have devastating consequences in tropical and subtropical regions. Records show a total of 504,000 deaths nationwide and 4.91 million deaths worldwide today, on May 25, 2021 (MARCOS, 2020).

Brazil has been facing dengue epidemics over the last 35 years. Failures monitored during the development of vector control and combat actions are pointed out as the main responsible for the increase in dengue case records in the territory (NAIRA, 2020).

To this end, we seek to bring to the discussion space some aspects that challenge the implementation and adoption of Public Policies that enable the control and combat of these two public health problems, seeking to understand and analyze these studies from works that can contribute to face the challenges that the entire community of professionals and employees of the single health system in the country faces.

The choice of the theme proposed a differentiated look at dengue co-infection and covid-19 in Brazil, because this area of activity is extremely important for concrete diagnoses, considering that this technology is also present in the followup of patients hospitalized by Covid-19. This literature review aimed to present co-infection of dengue and covid-19 in Brazil.

\section{Methodology}

This is a bibliographic review study, that is, a survey of theoretical reference from scientific publications, which is national ly and internationally involving dengue co-infection and covid-19 in Brazil.

The data collection occurred through the Coordination for the Improvement of Higher Education Personnel (CAPES) and Google Academic. The reference period was from April 2020 to March 2021.

The descriptors used were: "Coinfection" AND "simultaneous infection" AND "Sars Cov II" AND "Arbovirus". Inclusion criteria: works in English and Portuguese, published in the last five years, which deal with related topics involving dengue co-infection and covid-19 in Brazil. These, available for free online. Exclusion criteria include: works whose text is not available in full, duplicated, review, meta tonalysis, and also works that, after reading, were not related to the research objective.

Being selected 08 works being included, according to the eligibility criteria according to Figure 1.

In relation to the data appreciation, this study was conducted qualitatively, prioritizing the analysis of micro processes, understanding, interpreting and dialing these findings, inter-relating them through the established criteria.

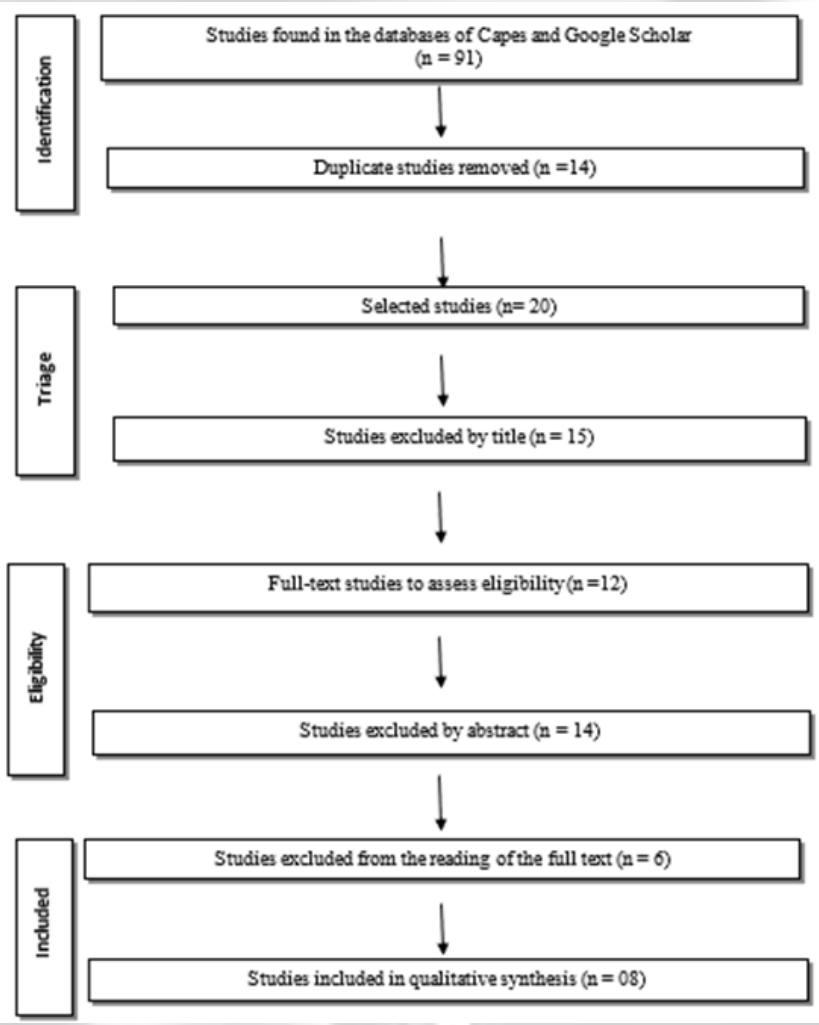

Figure 1. Flowchart of selection criteria and inclusion of studies.

\section{Results and Discussion}

Regarding the results found, a total of 91 works analyzed, however, only 08 works were included in the research, respecting the inclusion criteria.

Table 1. Demonstration of the works that make up the Integrative Review

\begin{tabular}{|c|c|c|c|c|c|c|}
\hline No. & Date & Title & Authors & Periodic & Goals & Findings \\
\hline & 2020 & $\begin{array}{l}\text { COVID - } 19 \\
\text { and Co dengue } \\
\text { epidemic: a } \\
\text { double problem } \\
\text { for overloaded } \\
\text { health systems } \\
\text { in developing } \\
\text { countries }\end{array}$ & $\begin{array}{l}\text { Misbahud } \\
\text { Din; Madiha } \\
\text { Asghar; } \\
\text { Muhammad } \\
\text { Ali }\end{array}$ & $\begin{array}{l}\text { Journal of } \\
\text { Medical } \\
\text { Virology }\end{array}$ & $\begin{array}{l}\text { To } \\
\text { highlight } \\
\text { the cases } \\
\text { about the } \\
\text { disease of } \\
\text { the new } \\
\text { coronavir } \\
\text { us } \\
\text { (SARS- } \\
\text { CoV-2) } \\
\text { and } \\
\text { Dengue. }\end{array}$ & $\begin{array}{l}\text { It has } \\
\text { been } \\
\text { noted } \\
\text { that } \\
\text { about } 100 \\
\text { to } 400 \\
\text { million } \\
\text { infections } \\
\text { per year } \\
\text { are } \\
\text { reported } \\
\text { due to } \\
\text { dengue } \\
\text { worldwid } \\
\text { e with } \\
25,000,00 \\
0 \text { deaths } \\
\text { annually. }\end{array}$ \\
\hline & 2020 & Coinfection, & Miah & Journal & Co- & It was \\
\hline
\end{tabular}




\begin{tabular}{|c|c|c|c|c|c|c|c|c|c|c|c|}
\hline & $\begin{array}{l}\text { CO EPIDEMIC } \\
\text { COVID - 19, } \\
\text { and dengue in } \\
\text { dengue } \\
\text { endemic } \\
\text { countries: a } \\
\text { serious health } \\
\text { problem }\end{array}$ & $\begin{array}{l}\text { Asaduzzama } \\
\mathrm{n} ; \quad \text { Asmaul } \\
\text { Husna }\end{array}$ & $\begin{array}{l}\text { Of } \\
\text { Medical } \\
\text { Virology }\end{array}$ & $\begin{array}{l}\text { infection } \\
\text { and co- } \\
\text { epidemic } \\
\text { of } \\
\text { COVID- } \\
19 \text { and } \\
\text { Dengue in } \\
\text { Endemic } \\
\text { Countries } \\
\text { are } \\
\text { presented. }\end{array}$ & $\begin{array}{l}\text { found } \\
\text { that } \\
\text { Dengue } \\
\text { in } \\
\text { endemic } \\
\text { countries } \\
\text { has a } \\
\text { history of } \\
\text { occurren } \\
\text { ce of } \\
\text { repeated } \\
\text { outbreak } \\
\mathrm{s} \quad \text { of } \\
\text { dengue, } \\
\text { that } \\
\text { during }\end{array}$ & & & $\begin{array}{l}\text { López } \\
\text { Medina; Pio } \\
\text { López; Juan } \\
\text { Carlos } \\
\text { Navarro; } \\
\text { Luis Perez } \\
\text { Garcia; } \\
\text { Euler } \\
\text { Mogollon } \\
\text { Rodriguez; } \\
\text { Alfonso J. } \\
\text { Rodríguez } \\
\text { Morales; } \\
\text { Alberto } \\
\text { Paniz } \\
\text { Mondolfi. } \\
\end{array}$ & & & $\begin{array}{l}\text { median of } \\
75,250 \\
\text { cases per } \\
\text { year. }\end{array}$ \\
\hline & & & & & $\begin{array}{l}\text { COVID- } \\
19 \quad \text { the } \\
\text { crisis of } \\
\text { the } \\
\text { situation } \\
\text { would be } \\
\text { very } \\
\text { difficult } \\
\text { to } \\
\text { manage if } \\
\text { the } \\
\text { dengue } \\
\text { epidemic } \\
\text { worsened } \\
\text { in these } \\
\text { countries. }\end{array}$ & 2020 & $\begin{array}{l}\text { Covid-19 and } \\
\text { dengue: double } \\
\text { blows to dengue } \\
\text { endemic } \\
\text { countries in } \\
\text { Asia }\end{array}$ & $\begin{array}{l}\text { Mirza Ryan; } \\
\text { Benedict } \\
\text { Yohan; } \\
\text { Rufika Shari } \\
\text { Abidin; } \\
\text { Firzan } \\
\text { Nainu; } \\
\text { Ahmed } \\
\text { Rakid; Israt } \\
\text { Jahan; Talha } \\
\text { Bin Emran; } \\
\text { Irfan Ullah; } \\
\text { Panta kritu; } \\
\text { Dhama } \\
\text { Kuldeep; R. } \\
\text { Tedjo }\end{array}$ & $\begin{array}{l}\text { Journal } \\
\text { Of } \\
\text { Medical } \\
\text { Virology }\end{array}$ & $\begin{array}{l}\text { Call the } \\
\text { double } \\
\text { blows in } \\
\text { endemic } \\
\text { countries } \\
\text { of } \\
\text { Dengue } \\
\text { and } \\
\text { COVID- } \\
19 \quad \text { in } \\
\text { Asia. }\end{array}$ & $\begin{array}{l}\text { It was } \\
\text { found that } \\
\text { Dengue is } \\
\text { an } \\
\text { important } \\
\text { public } \\
\text { health } \\
\text { problem } \\
\text { in all } \\
\text { tropical } \\
\text { and } \\
\text { subtropica } \\
1 \text { regions, } \\
\text { which } \\
\text { also } \\
\text { causes }\end{array}$ \\
\hline 2020 & $\begin{array}{l}\text { Dengue and } \\
\text { COVID - 19, } \\
\text { overlapping } \\
\text { epidemics? An } \\
\text { analysis of } \\
\text { Colombia }\end{array}$ & $\begin{array}{l}\text { Jaime A. } \\
\text { Cardona } \\
\text { Ospina; } \\
\text { Kovy } \\
\text { Arteaga } \\
\text { Livias; } \\
\text { Wilmer E. } \\
\text { Villamil } \\
\text { Gómez; } \\
\text { Carlos E. } \\
\text { Pérez Díaz; } \\
\text { D. Katterine } \\
\text { Bonilla } \\
\text { Aldana; }\end{array}$ & $\begin{array}{l}\text { Journal } \\
\text { Of } \\
\text { Medical } \\
\text { Virology }\end{array}$ & $\begin{array}{l}\text { Follow an } \\
\text { analysis } \\
\text { of } \\
\text { Dengue } \\
\text { and } \\
\text { COVID- } \\
19 \quad \text { in } \\
\text { Colombia }\end{array}$ & $\begin{array}{l}\text { It was } \\
\text { observed } \\
\text { that in the } \\
\text { last } 5 \\
\text { years } \\
(2015- \\
2019) \text { and } \\
\text { in the first } \\
5 \text { months } \\
\text { of } 2020 \\
\text { had a total } \\
\text { of } \\
452,980 \\
\text { dengue }\end{array}$ & & & Sasmono. & 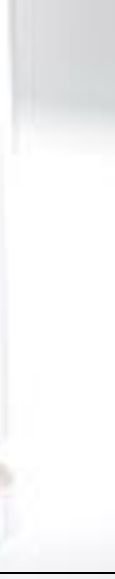 & & $\begin{array}{l}\text { this } \\
\text { disease by } \\
\text { any of the } \\
\text { four } \\
\text { serotypes } \\
\text { of Dengue } \\
\text { virus, } \\
\text { which is } \\
\text { transmitte } \\
\text { d by } \\
\text { mosquitoe } \\
s \quad \text { mainly } \\
\text { Aedes } \\
\text { aegypti. }\end{array}$ \\
\hline & & $\begin{array}{l}\text { Alvaro } \\
\text { Mondragon } \\
\text { Cardona; } \\
\text { Marco } \\
\text { Solarte } \\
\text { Portilla; } \\
\text { Ernesto } \\
\text { Martinez; } \\
\text { Jose Millan } \\
\text { Oñate; } \\
\text { Eduardo }\end{array}$ & $=0$ & & $\begin{array}{l}\text { cases were } \\
\text { reported } \\
\text { in } \\
\text { Colombia, } \\
\text { ranging } \\
\text { from } \\
26,279 \\
(2017) \text { to } \\
127,553 \\
(2019) \text {, } \\
\text { with a }\end{array}$ & 2020 & $\begin{array}{l}\text { Co-infection } \\
\text { between } \\
\text { Dengue and } \\
\text { COVID-19: } \\
\text { Need to } \\
\text { approach } \\
\text { endemic areas. }\end{array}$ & $\begin{array}{l}\text { Marcos } \\
\text { Saavedra } \\
\text { Velasco; } \\
\text { Christian } \\
\text { Chiara } \\
\text { Chilet; } \\
\text { Rafael } \\
\text { Pichardo } \\
\text { Rodriguesz; } \\
\text { Antonio } \\
\text { Grandez }\end{array}$ & $\begin{array}{l}\text { Revista } \\
\text { de la } \\
\text { Facultad } \\
\text { de } \\
\text { Ciencias } \\
\text { Médicas } \\
\text { de } \\
\text { Córdora. }\end{array}$ & $\begin{array}{l}\text { Observe } \\
\text { the } \\
\text { impact of } \\
\text { coronavir } \\
\text { us disease } \\
2019 \\
\text { around } \\
\text { the world, } \\
\text { and also } \\
\text { the } \\
\text { distributi }\end{array}$ & $\begin{array}{l}\text { It was } \\
\text { observed } \\
\text { that there } \\
\text { is the } \\
\text { possibility } \\
\text { of co- } \\
\text { infection } \\
\text { between } \\
\text { Dengue } \\
\text { and } \\
\text { COVID- }\end{array}$ \\
\hline
\end{tabular}


4 Barbosa, P.M.S.; Lima, A.F.P.S.; Silva, E.T.B.; Silva, E.B.; Lima, J.B.A.S.; Ferreira, J.V.T.; Damasceno, R.M.P.; Baroni, B.M.L.N.; Nascimento, M.M.S.T.; Neto, F.M.A.; Silva, M.M.Q.; Álvares, E.B.S.O. Dengue Co-infection and COVID-19 in Brazil, 2020: Literature Review...

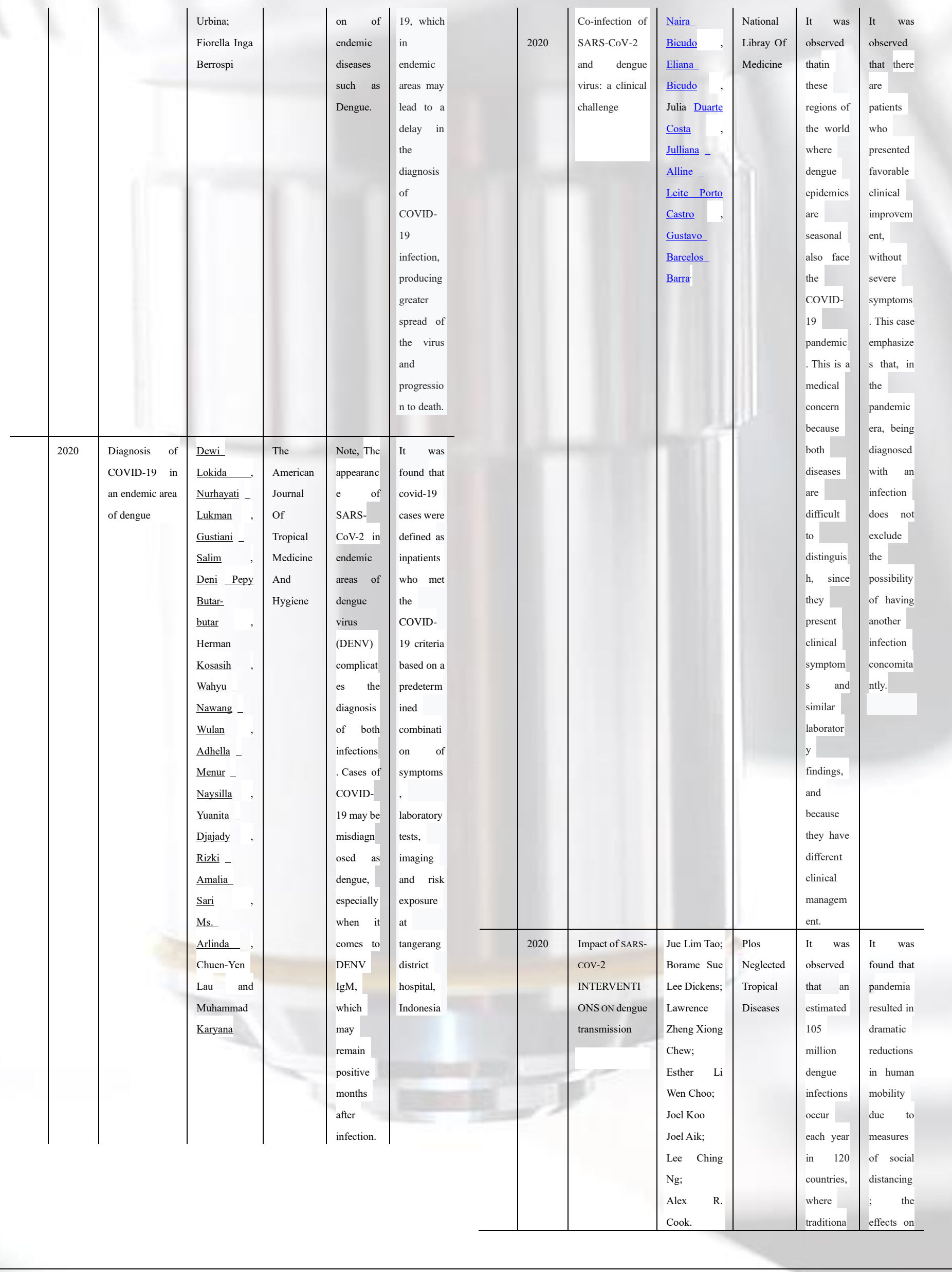




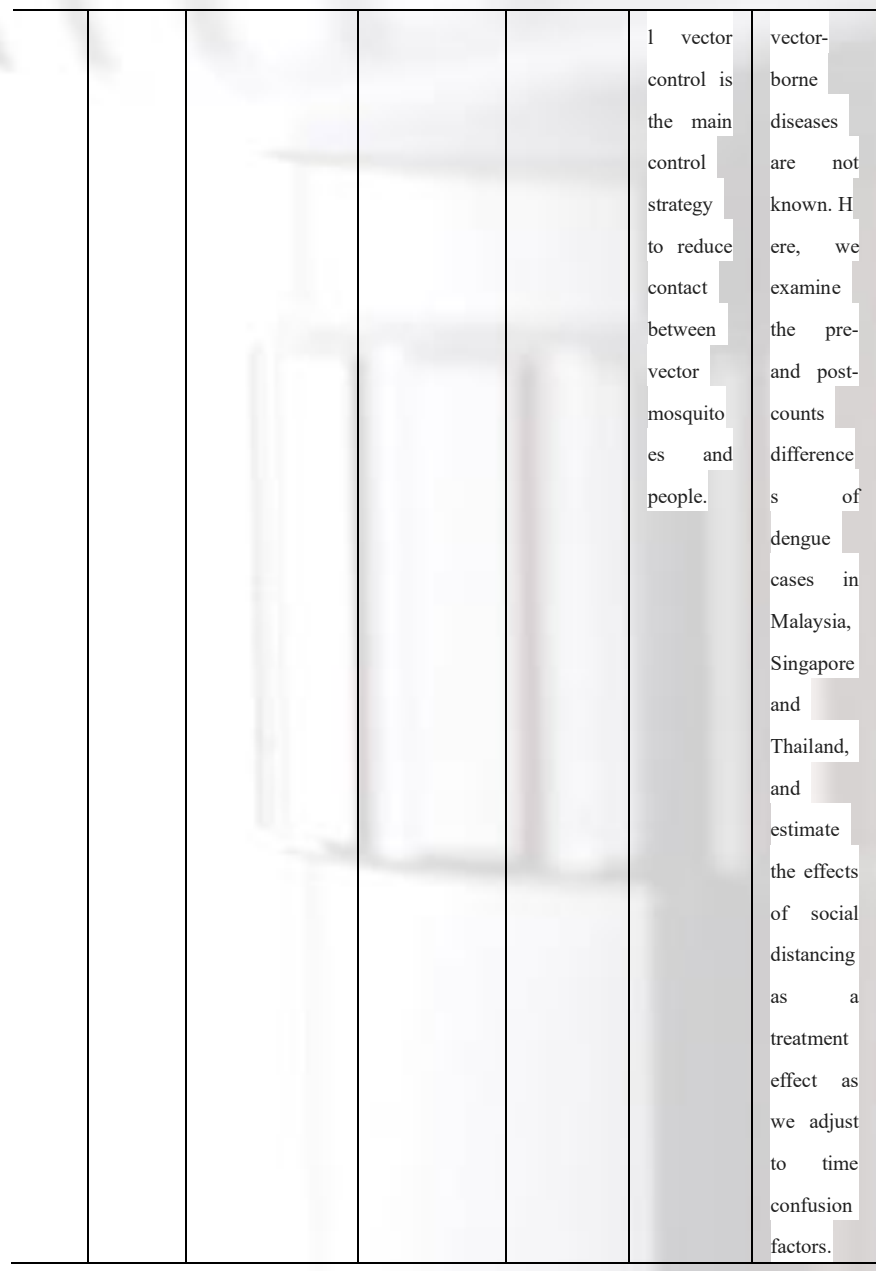

To this end, in the following sections we have the main points that the authors consulted discuss about dengue coinfection and covid-19 in Brazil.

In relation to dengue behavior in endemic countries, this pathology has a history of repeated outbreaks, this is one of the main determinants that directly imply the current crisis experienced with the arrival of the pandemic (ASADUZZAMAN et.al., 2020). According to Mirza et. al., (2019) Dengue is an important public health problem in all tropical and subtropical regions, transmitted by mosquitoes mainly Aedes aegypti.

The possibility of co-infection between Dengue and COVID-19 exists, mainly in endemic areas, which may lead to a delay in the diagnosis of COVID-19 infection, producing greater spread of the virus and progression to death (MARCOS et. al., 2020).

\section{References}

[1] Misbahud Din; Madiha Asghar; Muhammad Ali. COVID - 19 e coepidemia da dengue: um problema duplo para sistemas de saúde sobrecarregados em países em desenvolvimento. Journal Of Medical Virology 2020.

[2] Mirza Ryan; Benedict Yohan; Rufika Shari Abidin; Firzan Nainu; Ahmed Rakid; Israt Jahan; Talha Bin Emran; Irfan Ullah; kritu Panta; Kuldeep Dhama; R. Tedjo Sasmono. Covid-19 e dengue: golpes duplos para países endêmicos de dengue na Ásia. Journal Of Medical Virology 2020.

[3] Marcos Saavedra Velasco; Christian Chiara Chilet; Rafael Pichardo Rodriguesz; Antonio Grandez Urbina; Fiorella Inga Berrospi. Coinfecção entre Dengue e COVID-19: Necessidade de Abordagem em áreas endêmicas. Revista de la Facultad de Ciencias Médicas de Córdora, 31 Mar 2020, 77(1):52-54 Language: spa DOI: 10.31053/1853. 0605.v77.n1.28031 PMID: $32238260 / 2020$.

[4] Naira Bicudo, Eliana Bicudo, Julia Duarte Costa, Julliana Alline Leite Porto Castro, Gustavo Barcelos Barra. Coinfecção de SARS-CoV-2 e vírus da dengue: um desafio clínico. National Libray Of Medicine. 2020

[5] Asaduzzaman Miah; Asmaul Husna. Coinfecção, Co epidemia de COVID - 19, e dengue na dengue - países endêmicos: um sério problema de saúde. Journal Of Medical Virology. 2020

[6] Jaime A. Cardona Ospina; Kovy Arteaga Livias; Wilmer E. Villamil Gómez; Carlos E. Pérez Díaz; D. Katterine Bonilla Aldana; Álvaro Mondragon Cardona; Marco Solarte Portilla; Ernesto Martinez; Jose Millan Oñate; Eduardo López Medina; Pio López; Juan Carlos Navarro; Luis Perez Garcia; Euler Mogollon Rodriguez; Alfonso J. Rodríguez Morales; Alberto Paniz Mondolfi. Dengue e COVID - 19, epidemias sobrepostas? Uma análise da Colômbia. Journal Of Medical Virology 2020.

[7] Dewi Lokida, Nurhayati Lukman , Gustiani Salim , Deni Pepy Butar-butar, Herman Kosasih , Wahyu Nawang Wulan, Adhella Menur Naysilla , Yuanita Djajady , Rizki Amalia Sari , Dona Arlinda, ChuenYen Lau e Muhammad Karyana. Diagnóstico de COVID-19 em área endêmica de dengue. The American Journal Of Tropical Medicine And Hygiene. 2020.

[8] Jue Tao Lim; Borame Sue Lee Dickens; Lawrence Zheng Xiong Chew; Esther Li Wen Choo; Joel Ruihan Koo; Joel Aik; Lee Ching Ng; Alex R. Cook. Impacto das intervenções SARS-COV-2 na transmissão da dengue. Plos Neglected Tropical Diseases. 2020.

\section{Conclusion}

It was found that the possibility of co-infection between Dengue and COVID-19 exists, mainly in endemic areas, which may lead to a delay in the diagnosis of COVID-19 infection, producing greater dissemination of the virus and progression to death. 